\title{
Diabetes Mellitus in Egypt in Short
}

\section{Ahmed Osama Soliman*}

Helwan University, Cairo, Egypt

\begin{abstract}
Egyptians have great efforts in facing Diabetes through establishing associations, organizations and health campaigns. "Egyptian Society of Diabetic Foot" (ESDF) which mainly concerns on counseling diabetics how to take care of their feet to avoid diabetic foot. Also "Egyptian Pharmaceutical Students' Federation" (EPSF) has made many health campaigns to prevail health awareness among people and how to take care of themselves, other diabetics and their diet. Also, "Misr El-Khier" -an Egyptian charity organization- has a great share in facing Diabetes through scientific research on stem cells therapy in treating Diabetes. All share in giving diabetics a hope in cure and a well healthy life.
\end{abstract}

\section{Keywords: Associations, Diabetes, Awareness, Health}

Diabetes Mellitus is a real problem that influences the world as a whole and Egypt in particular, the Ancient Egyptian physician 'Hesyra' described it in approximately 3000 B.C. In fact, Ancient Egypt was the first civilization known to have studied medicine extensively, and the earliest written reference to Diabetes is attributed to the Upper Egyptian Ebers Papyrus circa 1550 B.C., we can see that Diabetes has been affecting lives for thousands of years ,and according to "The National Medical Journal of India", ancient Indians knew diabetes -which they called "sweet urine disease"- by determining if ants were attracted to a person's urine!.

Regarding Egyptian society nowadays, Diabetes is widespread in many families, nearly $10.4 \%$ of the Egyptian population (aged 10 - 79 years) have Diabetes as it is mainly inherited in Egyptian families, moreover Egyptians unhealthy diet may contribute to Diabetes' spread too.

Diabetics in Egyptian society may suffer from many side effects that probably affect badly on their lives as: diabetic foot, poor circulation, neuropathy, retinopathy, dermopathy, etc., therefore associations -like "Egyptian Society of Diabetic Foot" (ESDF)- have been established to face these dangers, also ESDF holds annual conference about Diabetic foot.

There are two main issues that "The ministry of health and population" in Egypt and other Egyptian associations against Diabetes concern on, the first issue is awareness campaigns about Diabetes to prevail education of how to deal with your diabetic family member, what to do to if you faced an emergency diabetic case and the right healthy diet for diabetics. The other issue is supplying the pharmacies and hospitals with Diabetes medications especially insulin and having stocks to provide health units in shortages and emergency cases [1-6].

Diabetics in Egypt need advancement in the way of counseling and treatment; the future of diabetic care in Egypt rests on the public education, expertise diagnostic, preventive and treatment strategies, and resources of research funding. With these assets, we can progress strategically towards overcoming this problem by means as:

- Establishing organizations dedicated to the promotion of diabetic care and research in Egypt as: "Misr El-Khier" -an Egyptian charity organization- which contributes to Diabetes research in Egypt, it funds the entire phases of the research performed by Dr. Mohamed Ghoneim who is responsible for the research, there are two phases; the first one -already doneis to extract stem cells from lab rats and convert them into Insulin producing cells and inject them into lab rats which are infected with Diabetes, while the second phase which they are still working on is to do the experiment on a human volunteer.

- Developing educational programs focused on the prevention and delay of Diabetes and its complications via behavior modification, exercise, diet, and weight management in children and adults as: 'Assistance to Youngsters with Diabetes' (AYD), this is an ambitious project and its ultimate objective is to enhance the quality of life of children with diabetes in Egypt through the provision of structured therapeutic health education. The founders of AYD are working to create a network of 'Diabetes schools' for children with the condition and their parents.

- Embracing and encouraging the initiatives like: home glucose monitoring and Diabetes medical convoys, Egyptian Pharmaceutical Students' Federation (EPSF) does so as on $14^{\text {th }}$ November -world Diabetes day- they measure blood glucose level randomly for as many persons as they can, also medical care initiatives to diabetics are held as done by the "Egyptian Diabetic Care Association" through initiating the $1^{\text {st }}$ annual international youth camps in 1978 which yielded the establishing of the 'International organization for Diabetes youth clubs' in 1989, also magazine for diabetes education is published.

Eventually, Despite Diabetes Mellitus prevalence, we can defeat it with our great will which is translated in hard work of counseling, campaigns, convoys and research advancement day by day hoping in a better future.

*Corresponding author: Ahmed Osama Soliman, Helwan University, NonUS/Non-Canadian 11176, Cairo, Egypt, Tel: +20 0122910 7886; E-mail: dr.ahmedosama_22@yahoo.com

Received November 05, 2013; Accepted December 06, 2013; Published December 11, 2013

Citation: Soliman AO (2013) Diabetes Mellitus in Egypt in Short. J Diabetes Metab 4: 318. doi:10.4172/2155-6156.1000318

Copyright: (C 2013 Soliman AO. This is an open-access article distributed under the terms of the Creative Commons Attribution License, which permits unrestricted use, distribution, and reproduction in any medium, provided the original author and source are credited. 


\section{References}

1. International Diabetes Federation, Initiation of Diabetes an education (2011) The impact of initiation of an educational and preventive foot care center for subjects with Diabetes in Alexandria, Egypt (ST07-004).

2. World Health Organization.

3. Egyptian Diabetic Care Association.

\section{Egyptian Society of Diabetic Foot}

5. Laila Sioufi, Azza Shaltout (2005) Improving the quality of life of young people with diabetes in Egypt. Diabetes voice 50: 35-39.

6. Misr El-Kheir, Scientific research 